\title{
What is the Disease? Engaging the Problem of Witchcraft in Africa
}

\author{
David Tonghou Ngong
}

In "Christian Pastors and (Alleged) Child Witches in Kinshasa, DRC," Robert Priest, Albert Ngolo, and Timothy Stabell (2020) have engaged one of the most critical issues in contemporary African Christianity-the issue of witchcraft in general and the accusation of children as witches in particular. By conducting their ethnographic work in Kinshasa, a context where the accusation of children as witches has led to dire and deplorable consequences for these children, they not only bring the issue into sharper relief but also intimate that it should be addressed with some urgency. As the research shows, accused children have been thrown into the streets and some of them have died because of these accusations. Given that the churches play a significant role in the accusation of children as witches, sampling the views of pastoral leaders about the issue, and working with them to think through how it may be assuaged, appear to be significant steps in the right direction. Given that pastoral leaders are thought leaders in their churches and communities, working through them to limit the accusation of children as witches appears to be one of the best ways to address the problem.

Another significant contribution the project makes is that it helps us to see that belief in witchcraft and the accusation of children as witches is not only found in Pentecostal churches, as recent literature on the issue seems to suggest, but cuts across church traditions and even the educational level of pastoral leaders. This leads one to wonder whether this is so because of what has been called the Pentecostalization of African Christianity (the claim that Pentecostal beliefs and practices have spread to other church traditions) or whether it predates this recent phenomenon. Perhaps more work needs to be done to determine why all church traditions in Kinshasa appear to be affected by the phenomenon.

As I read through the article, however, a pressing question that came to me was one that was raised by the medical anthropologist, Gwyn Prins, regarding the theory and practice of colonial medicine in Africa. In a very influential essay entitled, "But What Was the Disease?," Prins argued that colonial medicine inadequately conceptualized foundational issues relating to illness and health in Africa, thus proposing solutions for healing that did not quite hit the mark. An adequate conceptualization of foundational issues regarding how an illness such as sleeping sickness was spread and contained in precolonial Africa, he suggested, would lead to better handling of the illness. ${ }^{1}$ Similarly, an adequate diagnosis of foundational issues leading to the spread of the accusation of children as witches need to be made if the matter is to be adequately addressed. By focusing on the moment of accusation and what pastoral leaders may do about it, it seems the project focused on addressing the symptoms of the illness rather than the foundational issues that gave birth to them. Also, by focusing on the moment of accusation the project seems to diagnose the foundational issues as located in individual and family dynamics. But what if the foundational issue is bigger than specific individual and family dynamics? What if the foundational issues are located in the social and cultural imaginaire into which people are socialized and from which they draw their interpretations of the world? What if this imaginaire is seen as central to the growth of Christianity in Africa, as the Ghanaian theologian Kwame Bediako claimed? ${ }^{2}$ Is the Christian faith or Christian theology capable of arresting an imaginaire that seems to give it life? Would challenging

' Gwyn Prins, "But What Was the Disease? The Present State of Health and Healing in African Studies," Past \& Present 124 no. 1 (August 1989): 159-179.

${ }^{2}$ Kwame Bediako calls this imaginaire the "primal imagination," and sees it as the central context for the spread of Christianity in Africa. See Kwame Bediako, Jesus and the Gospel in Africa (Maryknoll, NY: Orbis Books, 2004), 85-89. 
this imaginaire not place Christianity in the unenviable position of the proverbial crocodile that eats its own eggs? What if the foundational issues are located in a political economy that daily saps the lives of the damned of this world, many of whom are found in Kinshasa?

These questions led me to see two broad dynamics that need to be engaged if we are to put a significant dent on the imagination that gives birth to the accusation of children as witches in some places in Africa. The first is what I have called a spiritualized imagination which often bends towards spiritual interpretations of the world. My own work as a theologian has focused on contesting the spiritualized imagination in which the notion of witchcraft is located. This imagination has been hailed in the study of African Christianity as the fertile soil that has led to the growth of the Christian faith in Africa. Thus, rather than challenging this imagination, it is sometimes presented as an imagination that needs to be nurtured in order to fend off atheism or the westernization of African Christianity. In "Christian Pastors and (Alleged) Child Witches in Kinshasa, DRC," our authors note this issue in comparing the situation of witchcraft accusation in Africa today and colonial America. The tension between challenging this imagination and the adverse effect it may have on Christian belief is one that needs to be wrestled with. Some basic questions this imaginaire raises include the following: how can one save the church from an unholy alliance with the accusation of children as witches while at the same time ensuring that Christian belief is not adversely affected? Does Christianity enjoy the possibility for growth only where the witchcraft imagination is preserved? If so, can Christianity adequately engage this imagination in order to stem the tide of accusation of children as witches? If it can, what would need to be done for such accusations to diminish? "Christian Pastors and (Alleged) Child Witches" points to some directions that may be taken in addressing these questions, but the questions remain open.

Our authors inform us of the process of training pastoral leaders to critically engage the accusations of children as witches, part of which is the charge that these pastors should treat the accusations as allegations rather than fact. Among these pastors, however, challenging the central issue of belief in the existence of witches is seen as quite problematic if not corrosive to Christian belief. Many of them seem to assume that to be Christian is to believe in witches so that, in one case, a pastor who attempted to challenge this belief was seen as unreliable. However, my own work has challenged this way of thinking, arguing that a central way of engaging the issue of witchcraft in Africa is to present a frontal challenge to the worldview that gives it life. While the individualized pastoral response this project encourages may begin to challenge this worldview, the fact that the pastors who administer the process themselves do not seem to be critical of the belief in witchcraft seems to skirt the foundational problem for the symptom. It may well be that challenging the symptom may eventually lead to addressing the foundational imaginaire that breeds it. However, a direct challenge of this imaginaire is still needed.

A further foundational dynamic that animates the belief in, and accusations of children as, witches is political and economic. This political and economic foundation is described as follows by the CIA Factbook:

Despite a wealth of fertile soil, hydroelectric power potential, and mineral resources, the Democratic Republic of Congo (DRC) struggles with many socioeconomic problems, including high infant and maternal mortality rates, malnutrition, poor vaccination coverage, lack of access to improved water sources and sanitation, and frequent and early fertility. Ongoing conflict, mismanagement of resources, and a lack of investment have resulted in food insecurity; almost 30 percent of children under the age of 5 are malnourished. The overall coverage of basic public services-education, health, sanitation, and portable water-is very limited and piecemeal, with substantial regional and rural/urban disparities. ${ }^{3}$

In this context, life has become very precarious and uncertain for many. The family dynamics in which the accusation of children as witches often takes place is not unconnected to this precarity and the attempt to understand and explain it. A pastoral engagement of the situation therefore should take into account how this broader political and economic dynamics continuously engenders this unwholesome imagination. Focusing on individual families, as this project does, may alleviate the suffering of these accused children but it also focuses on the symptoms rather than the foundational issues.

It has often been argued that modernity has not limited witchcraft accusations in Africa, as some thought it would. My own work has argued that the broader modern conditions that may limit such

${ }^{3}$ The World Factbook, The Democratic Republic of Congo, "People and Society," available at:

https://www.cia.gov/library/publications/the-world-factbook/geos/cg.html. Accessed December 18, 2019. 
accusations have been skewed in Africa. ${ }^{4}$ This point is emphasized by the anthropologist Ralph Austen who argues that witchcraft accusations diminished in Western Europe under modern conditions of industrialization. In Africa, however, modernity came with significant marginalization of the many who live in conditions of what has been described as abjection. ${ }^{5} \mathrm{It}$ is this condition of abjection that the CIA description of the situation in the DRC captures. African modernity therefore represents the dark side of modernization, a rapacious version of modernity that encourages cannibalism often captured in witchcraft accusations. African modernity is not the kind of modernity that will dent belief in witchcraft but rather one which raises prospects for accusations. This modernity has therefore led to the accusation of children as witches. Pastoral care in the context of the accusation of children as witches should therefore not be limited to family dynamics but should also address the broader economic and political issues that characterize a cannibalistic modernization in Africa. How this should be done, is the question to be probed.

Two broad dynamics, therefore, need to be kept in mind in any attempt to address the issues of the accusation of children as witches in Kinshasa and other parts of Africa-Christianity's blessing of the imagination that breeds these accusations and the rapacious political economy that creates abjection and penury. These accusations may hardly be adequately addressed if these are not also engaged.

\section{References}

Austen, Ralph A. 1993. The Moral Economy of Witchcraft: An Essay in Comparative History. In Modernity and Its Malcontents: Ritual and Power in Postcolonial Africa. Jean and John Comaroff, eds. Pp. 89-110. Chicago: The University of Chicago Press.

Bediako, Kwame. 2004. Jesus and the Gospel in Africa. Maryknoll, NY: Orbis Books.

Ngong, David T. 2012. Stifling the Imagination: A Critique of Religious and Anthropological Normalization of witchcraft in Africa. Asian and African Studies 11:144181.

. 2014. Reading the Bible in Africa: A Critique of Enchanted Bible Reading. Exchange 48: 174-191.
Prins, Gwyn. 1989. But What Was the Disease? The Present State of Health and Healing in African Studies. Past \& Present 124 (1): 159-179.

Priest, Robert J., Abel Ngolo and Timothy Stabell. 2020. Christian Pastors and Alleged Child Witches in Kinshasa, DRC. On Knowing Humanity Journal 4(1):1-51.

The World Factbook. 2020. The Democratic Republic of Congo. "People and Society." https://www.cia.gov/library/publications/the-worldfactbook/geos/cg.html. Accessed December 18, 2019.

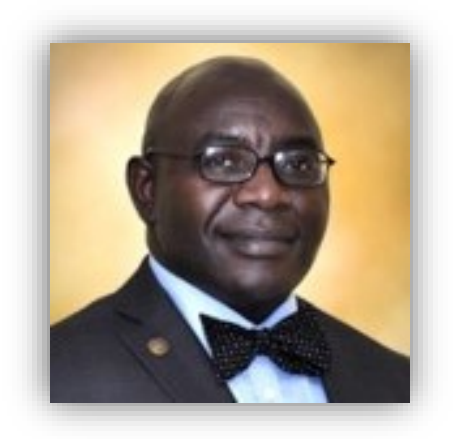

David Tonghou Ngong (Ph.D., Baylor University) is originally from Cameroon, Africa, and currently Associate Professor and Chair of the Department of Religion and Theology, Stillman College, Tuscaloosa, Alabama. His research focuses on dynamics of contemporary African theology. In addition to numerous published journal articles, he is author of The Holy Spirit and Salvation in African Christian Theology (Peter Lang, 2010) and, most recently, editor of $A$ New History of African Christian Thought (Routledge, 2017).

Author email: Dngong@stillman.edu

\footnotetext{
"See David T. Ngong, "Stifling the Imagination: A Critique of Religious and Anthropological Normalization of Witchcraft in Africa," Asian and African Studies 11 (2012): 144-181; Idem, "Reading the Bible in Africa: A Critique of Enchanted Bible Reading," Exchange 43 (2014): 174-191.
}

Ralph A. Austen, "The Moral Economy of Witchcraft: An Essay in Comparative History," in Modernity and Its Malcontents: Ritual and Power in Postcolonial Africa, ed. Jean and John Comaroff (Chicago: The University of Chicago Press, 1993), 89-110. 